TITLE:

\title{
Structural characterization and chromosomal localization of the MAGE-E1 gene(Abstract_要旨)
}

$\operatorname{AUTHOR}(S):$

Kawano, Yozo

\section{CITATION:}

Kawano, Yozo. Structural characterization and chromosomal localization of the MAGE-E1 gene. 京都大学, 2002, 博士(医学)

ISSUE DATE:

2002-05-23

URL:

http://hdl.handle.net/2433/149322

RIGHT: 


\begin{tabular}{|c|c|}
\hline 名 & $\begin{array}{llll}\text { かわ } & 9 & \text { 汸 } & \text { ぞう } \\
\text { 河 野 } & \text { 洋 }\end{array}$ \\
\hline 学位(専攻分野) & 博 士 (医 学) \\
\hline 学 位 記 番 号 & 医 博 第 2509 号 \\
\hline 学位授与の日付 & 平成 14 年 5 月 23 日 \\
\hline 学位授与の要件 & 学位規則 第 4 条第 1 項 該 当 \\
\hline 研究科・専攻 & 医学研究科外科系専攻 \\
\hline 位論文題目 & $\begin{array}{l}\text { Structural characterization and chromosomal localization of the } \\
\text { MAGE-E1 gene } \\
\text { (MAGE-E1 遺伝子のゲ) ム構造解析及びその遺伝子座の同定) } \\
\text { 河野洋三, 佐々木学, 中平健祐, 吉峰俊樹, 清水恵司, 和田洋巳, 池中一裕 }\end{array}$ \\
\hline
\end{tabular}

\section{論 文内容 の 要 旨}

以前, serial analysis of gene expression（SAGE）法を用いて，腫瘍特異抗原である melanoma-associated antigen (MAGE) ファミリーの新規遺伝子, MAGE-E1をクローニングした（参考論文 1 ）。

今回，この遺伝子の悪性腫瘍に対する診断，治療の標的分子としての臨床応用の可能性を探るべく，プロモーター領域を 含めたゲノム構造の解読解析と遺伝子座の同定を行った。

我々は MAGE-E1 のゲノム配列を含む human BAC clone を Research Genetics 社のライブラリースクリーニングサー ビスにより入手した。各種制限酵素にて消化した BAC DNA に対し，MAGE-E1 の cDNA をプローブとしたサザンブロ ッティングを行い，MAGE-E1 のゲノム配列を含むフラグメントをサブクローニングした後，そのシークエンス解析を行 った。また遺伝子座の同定には Radiation hybrid mapping 法を用いた。

解析の結果, MAGE-E1 gene は13個の exonからなっており，他の MAGE family との比較にて，そのゲノム構造は MAGE-D と酷似していた。遺伝子座に関しても MAGE-D と同様にXp11 であった。対照的に MAGE-A〜C とはその ゲノム構造に類似性を見ず，それらの構造比較より，MAGE-D，E1は MAGE-A 〜 C の ancestral gene である可能性も 考えられた。プロモーター領域に㧍ける転写因子結合部位予測では，悪性腫瘍よりも血球系の分化や形質転換に関与する因 子の結合部位の存在が予想された。MAGE family の機能は, MAGE-D family においてその一部が明らかになっている のみであり，いずれも細胞増殖やアポトーシスへの関与を示唆するものである。MAGE-D と遺伝子配列の相同性が高く， ゲノム構造も酷似しており，遺伝子座も同一である MAGE-E1 は同様の機能を持つ可能性があり，今後その機能を明らか にすることにより，その発現確認や発現制御が臨床診断や治療に応用可能となる可能性がある。

\section{論 文 審 査の 結 果の 要 旨}

MAGE-E1 は悪性膠芽腫に高発現し正常アストロサイトに発現を認めない新規遺伝子として Serial analysis of gene expression 法により同定された Melanoma-associated antigen（MAGE）ファミリー遺伝子である。また，本遺伝子は悪性膠 芽腫以外にも各種悪性腫掦に広く発現し，正常組織にははとんど発現を認めないことも明らかとなった。そこで本研究にお いて，そのゲノム構造の解読解析と遺伝子座の同定を行った。

MAGE-E1 のゲノム配列を含むBAC DNA を各種制限酵素にて消化し, MAGE-E1 の cDNA をプローブとしたサザン ブロッティングを行い, MAGE-E1 のゲノム配列を含むフラグメントをサブクローニングした後，そのシークエンス解析 を行った。その結果, MAGE-E1 遺伝子は13個の exon からなり, 他の MAGE family との比較にてゲノム構造は MAGE - A 〜 C とは類似性を見ず MAGE-D と酷似していることが判明した。次に Radiation hybrid mapping 法を用いて MAGE-E1 遺伝子座の同定を行ったところ, 遺伝子座も MAGE-D と同様にXp11 であることが明らかとなった。アミノ 酸配列の解析においても MAGE-E1 は MAGE-D と78.3\%と高いホモロジーを認めた。 
以上の様に MAGE-E1のゲノム構造を明らかにしたことは, 今後の MAGE-E1 の臨床応用に向けての機能解析に寄与 するところが大きい。

したがって, 本論文は博士 (医学) の学位論文として価值あるものと認める。なお，本学位授与申請者は，平成14年 3 月 18日実施の論文内容とそれに関連した試問を受け，合格と認められたものである。 